\title{
The Role of Profitability in the Effect of Company Growth on the Debt Policy
}

\author{
Akhmadi Akhmadi ${ }^{1}$, Dabela Yunia ${ }^{1} \&$ Robiyanto Robiyanto ${ }^{2}$ \\ ${ }^{1}$ Faculty of Economics and Business, Universitas Sultan Ageng Tirtayasa, Serang, Indonesia \\ ${ }^{2}$ Faculty of Economics and Business, Satya Wacana Christian University, Salatiga, Indonesia \\ Correspondence: Akhmadi Akhmadi, Faculty of Economics and Business, Universitas Sultan Ageng Tirtayasa, \\ Serang, Indonesia. Tel: 62-859-4554-2292. E-mail: akhmadi@untirta.ac.id
}

Received: January 19, 2020

Accepted: February 20, 2020

Online Published: July 7, 2020

doi:10.5430/ijfr.v11n4p267

URL: https://doi.org/10.5430/ijfr.v11n4p267

\begin{abstract}
This study aims to examine the role of profitability as a mediating variable on the effect of company growth on debt policy. The samples were companies of textile and garment sub-sector listed on the Indonesia Stock Exchange in the 2014-2018 period. The results show that asset growth (AG) did not affect the debt to equity ratio (DER). In addition, return on asset (ROA) was found to have a positive effect on the DER. Meanwhile, the ROA could not mediate the effect of asset growth on the DER.
\end{abstract}

Keywords: asset growth, return on asset, debt to equity ratio, Indonesia Stock Exchange

\section{Introduction}

\subsection{Background of the Study}

Today, the economy of Indonesia is influenced by a number of companies developed rapidly. Brigham and Houston (2012) stated that the company's main goal is to increase the company value by increasing the prosperity of the owners or shareholders. Companies that could not achieve these objectives will experience difficulty in funding sources. Then, they will use external funding sources such as debt. The funding decision commonly used by managers is debt policy (Sutomo, Wahyudi, Rini Demi Pangestuti, \& Muharam, 2019). Brigham and Houston (2012) explained that debt policy is a policy on decisions taken by companies to carry out operations using financial leverage.

One sector that has made a major contribution to the country's economic development is the textile and garment industry companies. This industry is currently one of the drivers of national manufacturing growth, given that Indonesia is well respected and achieve the ninth rank of the world's textile and garment producers. The Indonesian government continues to encourage investment in this industry sector as it provides major contributions such as boosting the economy and creating great job opportunities. However, in the last five years, the development of the textile and garment industry had not been very encouraging. This industry experienced an average growth of only $2.28 \%$. This happened mainly because of two causes, such as high operational costs and sluggish export markets.

Increased debt occurs because companies use more funds from debt than funds from their own capital in operational activities. The trend of increasing debt in the sector can be caused by many factors. According to Halling, Yu, and Zechner (2016); Koutmos, Bozos, Dionysiou, and Lambertides (2018); Michalski et al. (2018), the factors included were the level of sales, asset structure, company growth, profitability, profits, tax protection, company scale, internal conditions of the company and macroeconomics. Many previous researchers have linked the company growth with debt policy. Research by Halling et al. (2016); Vithessonthi and Tongurai (2015) proved that company growth had a negative effect on debt policy. However, Handriani and Robiyanto (2018b); Wahyudi, Goklas, Rita, Hersugondo, and Laksana (2019) found the opposite. Different results were also found by Joni and Lina (2010) which proved that the company growth had no effect on debt policy.

Regarding the effect of profitability on debt policy, Balios, Daskalakis, Eriotis, Vasiliou, and McMillan (2016); Hoang (2015); Maneerattanarungrot and Donkwa (2018); Mateev, Poutziouris, and Ivanov (2013); Sutomo et al. (2019) found that profitability has positive effect on debt policy. On the contrary, Alhassan, Addisson, and Asamoah (2015); Chaibi and Ftiti (2015); Vithessonthi and Tongurai (2015) found that that profitability has a negative effect on debt policy. 
These results of several previous studies show inconsistency. It is believed that there are other variables such as profitability can affect the relationship between company growth and debt policy as mediating. Several studies suggested (i.e. Chavali and Rosario (2018); Mai (2017)) that profitability might be one of the factors believed to strengthen the relationship of company growth with debt policy. Hence, this present research is important, as there is a gap found in the relationship between company growth and debt policy by developing a research model. Regarding the aforementioned statement, the purpose of this study is to scrutinize the relationship between company growth and debt policy by developing a research model that employs the mediating variable such as profitability. Hopefully, the finding of this study can contribute to the financial literature regarding the importance of profitability as a mediating variable on the relationship between company growth and debt policy.

\subsection{Literature Review}

\subsubsection{Signaling Theory}

Bandyopadhyay and Barua (2016) explained that the signaling theory suggests how companies should give signals to financial statements. This theory also provides an overview of the importance of information released by the company to the owners or shareholders (Handriani \& Robiyanto, 2019; Robiyanto, Anggraeni, Nugraha, \& Lako, 2019).

\subsubsection{Pecking Order Theory}

Pecking order theory is one of the theories that underlie corporate funding decisions. Al-Ani and Al-Amri (2015); Dhingra and Dev (2016); Haron, Ibrahim, Nor, and Ibrahim (2013); Nijenhuis (2013); Serghiescu and Văidean (2014) explained that companies preferred internal financing from retained earnings. If external funding is needed, the company will first issue the safest security, starting with the issuance of convertible debt, and the last alternative is the shares (Puryandani, Kusumawati, \& Robiyanto, 2020).

\subsubsection{Company Growth}

Growth is a ratio illustrating the ability of a company to maintain its economic position in the midst of economic growth and its business sector (Sutomo et al., 2019). Eshima and Anderson (2017) revealed that growth explains how far the company places itself in the overall economic system or an economic system for the same industry.

\subsubsection{Profitability}

Profitability is a ratio to assess a company's ability to obtain profits. This ratio also provides a measure of the level of management effectiveness of a company (Handriani \& Robiyanto, 2018a, 2019; Muharam, Mawardi, Handriani, Puryandani, \& Robiyanto, 2020). Meanwhile, according to Aqil, Ahmed, Vveinhardt, and Streimikiene (2019), profitability is a ratio that measures the overall effectiveness of management focusing on the size of the level of profits obtained in relation to sales and investment.

\subsubsection{Debt Policy}

Debt policy is a policy taken by companies to finance using debt (Cheryta, Moeljadi, \& Indrawati, 2018; Sutomo et al., 2019). Brigham and Houston (2012) mentioned that debt policy is a policy on decisions taken by a company to run its operations using financial leverage.

\subsection{Hypotheses Development}

\subsubsection{The Effect of Company Growth on Debt Policy}

In the pecking order theory, it is explained companies with a high growth mean that they have sufficient internal resources for their activities (Dhingra \& Dev, 2016; Haron et al., 2013; Serghiescu \& Văidean, 2014). Empirically, this relationship is proven by Alhassan et al. (2015); Chaibi and Ftiti (2015); Vithessonthi and Tongurai (2015). For this reason, the first hypothesis that can be proposed is the higher the company's growth, the lower the debt ratio.

\subsubsection{The Effect of Company Growth on Profitability}

In the signaling theory, it is explained that a high investment is a signal of growth in the future. These signals are considered good news by investors which in turn will affect their perceptions of the company's financial performance which will ultimately affect profitability. Empirically, this relationship is in accordance with results found by Handriani and Robiyanto (2018b); Wahyudi et al. (2019). For this reason, the second hypothesis that can be proposed is the higher the company growth, the higher the profitability.

\subsubsection{The Effect of Profitability on Debt Policy}

In the pecking order theory, it is explained that the first choice in funding decisions is to use retained earnings, then use debt and equity. The higher the profit obtained by the company, the smaller the use of debt used in corporate funding 
because the company can use internal equity obtained from the retained earnings (Al-Ani \& Al-Amri, 2015; Dhingra \& Dev, 2016; Haron et al., 2013; Nijenhuis, 2013; Serghiescu \& Văidean, 2014). Empirically, this relationship is proven by Addisson, and Asamoah (2015); Chaibi and Ftiti (2015); Vithessonthi and Tongurai (2015). For this reason, the third hypothesis that can be proposed is the higher the profitability, the lower the company's debt ratio.

\section{Method}

\subsection{Population, Sample, and Data}

The population of this research was 20 companies. The sample was determined using a purposive sampling technique. The criteria were they should be subsectors of textile and garment companies listed on the Indonesia Stock Exchange and had a complete financial statement. Based on the criteria, a total of 16 companies was obtained as the samples. The type of data used was secondary and quantitative data obtained from the financial statements of the textile and garment subsector companies listed on the Indonesia Stock Exchange in the period of 2015 - 2018. The observation number in this study is 64 .

\subsection{Operational Variable}

The dependent variable is debt policy, proxied by debt to equity ratio (DER) - a ratio of total debt to total equity. The independent variable was the company's growth, proxied by the growth of total assets - by calculating the proportion of the increase in total assets from the previous year compared to the current year. Profitability, in this study, acts as an intervening variable and is proxied by return on assets (ROA) - the ratio of net income to total assets.

\subsection{Analytical Tool}

This study used analytical techniques including the classic assumption test intended to get the best model, partial hypothesis test (t-test) to test the effect of company growth, and profitability on debt policy partially, and mediation test with a special step analysis intended to test the effect indirectly. This analysis was done to examine the following research model:

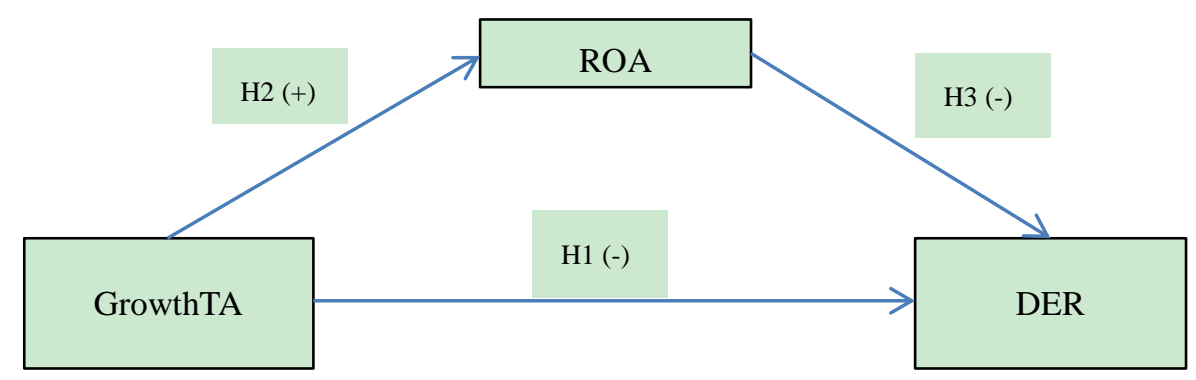

Figure 1

The path analysis of the above figure explains the direct effect of company growth on debt policy. It also explains the indirect effect (through profitability) of the company growth on debt policy.

\section{Results}

\subsection{Descriptive Statistics}

The result of descriptive statistics can be seen in Table 1 . The mean value of asset growth, DER, and ROA respectively are $6.655,-1.485$, and 3.121. They are lower than the standard deviation of 19.643, 35.089 and 40.868. Meanwhile, the maximum value of asset growth, DER, and ROA respectively are 113.53, 85.87, and 319.20. Meanwhile, the minimum values are $-20.27,-261.15$ and -23.10 and their median value is $4.60,1.565$ and 0.265 . 
Table 1. Descriptive statistics

\begin{tabular}{lcccccc}
\hline Variable & N & Mean & Median & $\begin{array}{l}\text { Std. } \\
\text { Deviation }\end{array}$ & Minimum & Maximum \\
\hline Asset Growth & 64 & 6.6544 & 4.6000 & 19.6435 & -20.27 & 113.53 \\
\hline Debt to Equity Ratio & 64 & -1.4850 & 1.5650 & 35.0899 & -261.15 & 85.87 \\
\hline Return on Asset & 64 & 3.1206 & 0.2650 & 40.8675 & -23.10 & 319.20 \\
\hline
\end{tabular}

Source: The Indonesia Stock Exchange, processed.

\subsection{Classic Assumption Test Results}

The result of the classic assumption test shows that it meets the assumption of the goodness of fit model in the regression model which includes normality, multicollinearity, heteroscedasticity, autocorrelation, and linearity test.

\subsubsection{Normality Test Result}

The normality test used the Kolmogorov-Smirnov parameter, producing a significance value of 0.000 . It is smaller than the cut-off value of 0.05 , indicating that there is an abnormality in the data distribution in the regression model. Removing the outlier was done on 20 observations and there was a total of 44 observation data remained. After being re-tested, a sig. value of 0.083 was found which is higher than 0.05 and indicated that there is no abnormality in the regression model.

\subsubsection{Multicollinearity Test Result}

The multicollinearity test used parameters of variance inflation factor (VIF) and tolerance, producing VIF for asset growth and ROA of $1.032<10$ respectively. This indicated that there is no multicollinearity in the regression model. The result of the multicollinearity test can be seen in the following Table 2 .

Table 2. Result of multicollinearity test

\begin{tabular}{ll}
\hline Variable & VIF \\
\hline Asset Growth & 1.032 \\
\hline Return on Asset & 1.302 \\
\hline
\end{tabular}

Source: The Indonesia Stock Exchange, processed.

\subsubsection{Heteroscedasticity Test Result}

The heteroscedasticity test used the Glejser test, resulting in significant value for asset growth of $0.350>0.05$. This indicated that there is no heteroscedasticity in the regression model. Similarly, the significance value of ROA is $0.240>$ 0.05 , showing that there is no heteroscedasticity in the regression model. The result of the Glejser test can be seen in the following Table 3.

Table 3. Result of Glejser test

\begin{tabular}{lll}
\hline Variable & t-statistics & $\begin{array}{l}\text { Probability } \\
\text { Value }\end{array}$ \\
\hline Asset Growth & 0.945 & 0.581 \\
\hline Return on Asset & 1.402 & 0.240 \\
\hline
\end{tabular}

Note: the dependent variable is absolute residual.

\subsubsection{Autocorrelation Test Result}

An autocorrelation test was performed using Durbin-Watson statistics. The results of the analysis show that the Durbin-Watson statistics are 2.014. It indicated that there is no autocorrelation in the regression model. 


\section{Discussion}

\subsection{The Effect of Asset Growth on Debt to Equity Ratio}

In Table 6, it can be seen that the regression coefficient value of the effect of the variable asset growth on the DER has a significance value of 0.871 which is greater than 0.05 . Therefore, it can be concluded that asset growth had no effect on the DER. This result does not support the pecking order theory which states that the companies with high growth would rely on internal sources to fund their investments. The results are also in contrast to studies by Alhassan et al. (2015); Chaibi and Ftiti (2015); Vithessonthi and Tongurai (2015). However, the results are in accordance with a study by Steven and Lina (2011) which proved that the company growth had no effect on the debt policy.

This result implies that there is a tendency where there would be no influence on the company's debt policy when the management decides to increase or decrease the company scale. Whether or not a company plans to increase or decrease its business scale, it does not necessarily influence the management to keep increasing its debt ratio or reducing its debt ratio. Therefore, no matter how often the management proposes a company development plan or decreasing the company scale, the debt ratio can still be increased or decreased if necessary, without considering the company development policies.

\subsection{The Effect of Return on Asset on Debt to Equity Ratio}

In Table 6, it can be seen that the regression coefficient value of the effect of return on asset toward the DER has a significance value of 0.014 which is smaller than 0.05 . Therefore, it could be concluded that the ROA had a positive effect on debt to equity ratio. This result is in contrast to the pecking order theory which states that the higher the profit, the smaller the debt ratio would be because the company could rely on their internal funds in the funding policy. The results are also not in line with the research by Addisson, and Asamoah (2015); Chaibi and Ftiti (2015); Vithessonthi and Tongurai (2015) which proved that high profitability decreased the debt ratio. However, similar results could be found in research by Balios et al. (2016); Hoang (2015); Maneerattanarungrot and Donkwa (2018); Mateev et al. (2013); Sutomo et al. (2019) which proved that the profitability had a positive effect on leverage (debt to equity ratio).

The results imply that there is a tendency for the company management to continue to increase its debt ratio although the company's ability to generate profits has increased significantly and vice versa where the company would decrease its debt ratio although there is a decrease in the company's ability to generate profits. The former is a decision that can only be taken when increasing profits can not significantly increase the ability of internal funds, so it still requires external funding support from debt. The later is a decision that can only be made when the decline in profits is not significant so that it does not influence the ability of internal funds which is still very strong and able to fund the company. Therefore, there could be enough reason to decrease the debt ratio.

Table 4. Result of regression analysis (Structure 1)

\begin{tabular}{|c|c|c|c|c|c|c|}
\hline \multirow{2}{*}{\multicolumn{2}{|c|}{ Model }} & \multicolumn{2}{|c|}{ Unstandardized Coefficients } & \multirow{2}{*}{$\begin{array}{l}\text { Standardized } \\
\text { Coefficients }\end{array}$} & \multirow[b]{2}{*}{$\mathrm{t}$} & \multirow[b]{2}{*}{ Sig. } \\
\hline & & $\mathrm{B}$ & Std. Error & & & \\
\hline \multirow[t]{2}{*}{1} & (Constant) & 0.877 & 0.263 & & 3.339 & 0.002 \\
\hline & Asset Growth & 0.014 & 0.024 & 0.090 & 0.586 & 0.561 \\
\hline
\end{tabular}

Table 5. Result of regression analysis (Structure 2)

\begin{tabular}{|c|c|c|c|c|c|c|}
\hline \multirow{2}{*}{\multicolumn{2}{|c|}{ Model }} & \multicolumn{2}{|c|}{ Unstandardized Coefficients } & \multirow{2}{*}{$\begin{array}{l}\text { Standardized } \\
\text { Coefficients } \\
\text { Beta }\end{array}$} & \multirow[b]{2}{*}{$\mathrm{t}$} & \multirow[b]{2}{*}{ Sig. } \\
\hline & & $\bar{B}$ & Std. Error & & & \\
\hline \multirow[t]{2}{*}{1} & (Constant) & -0.477 & 0.676 & & -0.705 & 0.485 \\
\hline & Asset Growth & 0.072 & 0.063 & 0.175 & 1.153 & 0.255 \\
\hline
\end{tabular}

Dependent Variable: Return On Assets 
Table 6. Result of regression analysis (Structure 3)

\begin{tabular}{|c|c|c|c|c|c|c|}
\hline \multirow{2}{*}{\multicolumn{2}{|c|}{ Model }} & \multicolumn{2}{|c|}{ Unstandardized Coefficients } & \multirow{2}{*}{$\begin{array}{l}\text { Standardized } \\
\text { Coefficients } \\
\text { Beta }\end{array}$} & \multirow[b]{2}{*}{$\mathrm{t}$} & \multirow[b]{2}{*}{ Sig. } \\
\hline & & $\mathrm{B}$ & Std. Error & & & \\
\hline \multirow[t]{3}{*}{1} & (Constant) & 0.946 & 0.248 & & 3.813 & 0.000 \\
\hline & Asset Growth & 0.004 & 0.023 & 0.024 & 0.163 & 0.871 \\
\hline & Return On Assets & 0.145 & 0.056 & 0.377 & 2.574 & 0.014 \\
\hline
\end{tabular}

Dependent Variable: Debt to Equity Ratio

\subsection{Mediation Test}

The regression equations of the effect of asset growth on debt to equity mediated by return on assets are as follows:

$$
\begin{gathered}
\text { Structure 1: DER }=0.877+0.014 \mathrm{AG}+\mathrm{e} \\
\text { Structure 2: } \mathrm{ROA}=-0.477+0.072 \mathrm{AG}+\mathrm{e} \\
\text { Structure 3: DER }=0.946+0.004 \mathrm{AG}+0.145 \mathrm{ROA}+\mathrm{e}
\end{gathered}
$$

The mediation test of the ROA on the effect of asset growth on DER using a causal step parameter. In Table 4., Structure 1 has a sig. value of 0.561 , which is greater than 0.05 . It explains that the asset growth had no significant effect on the DER. In Table 5, Structure 2 has a significance value of 0.255 , which is greater than 0.05 . It indicates that the asset growth had no significant effect on the return on assets. Meanwhile, in Table 6., Structure 3 has a sig. value of 0.871 , which is greater than 0.05 . It shows that asset growth had no significant effect on the debt to equity ratio. The sig. value of the return on assets on debt to equity is 0.014 , which is smaller than 0.05 and explains that the return on assets had a significant effect on the debt to equity ratio.

Noting that only Structure 3 which has a significant influential variable and no significant independent variables found in Structure 1 and Structure 2, while the requirement for a variable to be a mediating variable is the existence of significant results on Structure 2 and Structure 3, therefore, it could be concluded that the return on asset failed to be a mediating variable on the effect of asset growth on the debt to equity ratio. This result implies that high or low asset growth could not lead to an increase or a decrease in return on assets. Therefore, it did not have any impact on increasing or decreasing the debt to equity ratio. Thus, the asset growth could be a direct cause for increasing or decreasing the DER, even on a large scale. This seemed possible in companies with a high growth that was not directly responded with high profits where it was in a need of funding for a higher growth purpose. If their internal funds were too lacking in support (small profit contribution), the external funds such as debt were needed to support the corporate funding.

\subsection{Conclusions}

This study finds that asset growth did not significantly influence the DER. Thus, the asset growth could not be a direct cause of changes in the DER. While the ROA was found to have a positive effect on the DER. The results imply that there is a tendency for the company management to continue to increase its debt ratio although the company's ability to generate profits has increased significantly. On the other hand, the ROA was found to fail in mediating the effect of asset growth on DER. A high or low asset growth could not result in an increase or a decrease in return on assets. In addition, it did not have any impact on increasing or decreasing the DER.

Base on the findings, some implications for the investors and the creditors are (1) the investors need to pay attention to the profitability of textile and garment sector companies before investing in their funds; (2) The creditors must also pay attention to the company's profitability as increasing profitability will also enable the company to pay its debts. They should aware of the companies' profitability, so they can offer more debt to the companies as long as the companies' capital structure still appropriate.

This study implied that profitability has a direct effect rather than a mediating effect. This finding may happen because of the proxy used. Also, this study only examined one specific sector with a relatively limited number of companies which is the textile and garment sector in Indonesia. Future research may study other sectors with a greater number of companies such as basic and chemical industries or other manufacturing industries to avoid high variability and biases. Other proxies can be used also in future studies. 


\section{References}

Al-Ani, M. K., \& Al-Amri, M. S. (2015). The Determinants of Capital Structure: An Empirical Study of Omani Listed Industrial Companies. Business: Theory and Practice, 16(2), 159-167. https://doi.org/10.3846/btp.2015.471

Alhassan, A. L., Addisson, G. K., \& Asamoah, M. E. (2015). Market structure, efficiency and profitability of insurance firms in Ghana. International Journal of Emerging Markets, 10(4), 648-669. https://doi.org/10.1108/IJoEM-06-2014-0173

Aqil, M., Ahmed, R., Vveinhardt, J., \& Streimikiene, D. (2019). Factors Influencing the Profitability of Heavy Vehicle Industry: A Case of Pakistan. Montenegrin Journal of Economics, 15(1), 61-72. https://doi.org/10.14254/1800-5845/2019.15-1.5

Balios, D., Daskalakis, N., Eriotis, N., Vasiliou, D., \& McMillan, D. (2016). SMEs capital structure determinants during severe economic crisis: The case of Greece. Cogent Economics \& Finance, 4(1). https://doi.org/10.1080/23322039.2016.1145535

Bandyopadhyay, A., \& Barua, N. M. (2016). Factors determining capital structure and corporate performance in India: Studying the business cycle effects. The Quarterly Review of Economics and Finance, 61, 160-172. https://doi.org/10.1016/j.qref.2016.01.004

Brigham, E. F., \& Houston, J. F. (2012). Fundamentals of Financial Management. Cengage Learning.

Chaibi, H., \& Ftiti, Z. (2015). Credit risk determinants: Evidence from a cross-country study. Research in International Business and Finance, 33, 1-16. https://doi.org/10.1016/j.ribaf.2014.06.001

Chavali, K., \& Rosario, S. (2018). Relationship between capital structure and profitability: a study of non banking finance companies in India. Academy of Accounting and Financial Studies Journal, 22(1), 1-8.

Cheryta, A. M., Moeljadi, M., \& Indrawati, N. K. (2018). Leverage, Asymmetric Information, Firm Value, and Cash Holdings in Indonesia. Jurnal Keuangan dan Perbankan, 22(1), 83-93. https://doi.org/10.26905/jkdp.v22i1.1334

Dhingra, R., \& Dev, K. (2016). Determinants of Capital Structure-A Study of Oil Industry in India. International Journal of Engineering and Management Research, 6(1), 35-42.

Eshima, Y., \& Anderson, B. S. (2017). Firm growth, adaptive capability, and entrepreneurial orientation. Strategic Management Journal, 38(3), 770-779. https://doi.org/10.1002/smj.2532

Halling, M., Yu, J., \& Zechner, J. (2016). Leverage dynamics over the business cycle. Journal of Financial Economics, 122(1), 21-41. https://doi.org/10.1016/j.jfineco.2016.07.001

Handriani, E., \& Robiyanto, R. (2018a). Corporate finance and firm value in the Indonesian manufacturing companies. International Research Journal of Business Studies, 11(2), 113-127. https://doi.org/10.21632/irjbs.11.2.113-127

Handriani, E., \& Robiyanto, R. (2018b). Investment opportunity and industrial growth in Indonesia. International Journal of Business and Society, 19(2), 295-312.

Handriani, E., \& Robiyanto, R. (2019). Institutional ownership, independent board, board size, and firm performance: evidence from Indonesia. Contaduría y Administración, https://doi.org/10.22201/fca.24488410e.2018.1849

Haron, R., Ibrahim, K., Nor, F. M., \& Ibrahim, I. (2013). Dynamic adjustment towards target capital structure: Thailand evidence. Jurnal Pengurusan, 39, 73-82.

Hoang, T. V. (2015). Impact of Working Capital Management on Firm Profitability: The Case of Listed Manufacturing Firms on Ho Chi Minh Stock Exchange. Asian Economic and Financial Review, 5(5), $779-789$.

Joni, \& Lina. (2010). Faktor-Faktor Yang Mempengaruhi Struktur Modal. Jurnal Bisnis dan Akuntansi, 12(2), 81-96. https://doi.org/10.34208/jba.v12i2.187

Koutmos, D., Bozos, K., Dionysiou, D., \& Lambertides, N. (2018). The timing of new corporate debt issues and the risk-return trade-off. Review of Quantitative Finance and Accounting, 50(4), 943-978. https://doi.org/10.1007/s11156-017-0651-z

Mai, M. U. (2017). Mediation of CSR and Profitability on the Influences of GCG Mechanism to the Firm Value. 
Jurnal Keuangan dan Perbankan, 21(2), 253-264.

Maneerattanarungrot, C., \& Donkwa, K. (2018). Capital structure affecting firm value in Thailand. ABAC Journal, 38(2), 133-146.

Mateev, M., Poutziouris, P., \& Ivanov, K. (2013). On the determinants of SME capital structure in Central and Eastern Europe: A dynamic panel analysis. Research in International Business and Finance, 27(1), $28-51$. https://doi.org/10.1016/j.ribaf.2012.05.002

Michalski, G., Blendinger, G., Rozsa, Z., Cierniak-Emerych, A., Svidronova, M., Buleca, J., \& Bulsara, H. (2018). Can We Determine Debt To Equity Levels In Non-Profit Organisations? Answer Based On Polish Case. Engineering Economics, 29(5), 526-535. https://doi.org/10.5755/j01.ee.29.5.19666

Muharam, H., Mawardi, W., Handriani, E., Puryandani, S., \& Robiyanto, R. (2020). Corporate Governance Structure and Firm Performance in the Indonesian Capital Market. Quality - Access to Success, 21(174), 22-27.

Nijenhuis, K. T. (2013). Important factors in determining the capital structure of a company. Empirical evidence from Dutch companies. Thesis, University of Twente. Retrieved from https://essay.utwente.nl/64528/1/Master\%20thesis,\%20Important\%20factors\%20in\%20determining\%20the\%20capital $\% 20$ structure $\% 20$ of $\% 20$ a $\% 20$ company. $\% 20$ Empirical\%20vidence\%20from\%20Dutch\%20companies.pdf

Puryandani, S., Kusumawati, H. A., \& Robiyanto, R. (2020). Corporate Governance and Earnings Management Practices in Indonesian Banking Sector. Quality - Access to Success, 21(176), 102-108.

Robiyanto, R., Anggraeni, A. D., Nugraha, A. K. N. A., \& Lako, A. (2019). The Effect of Good Corporate Governance Mechanism on Firm Value of Indonesian Socially Responsible Firms. Quality - Access to Success, 20(173), 59-63.

Serghiescu, L., \& Văidean, V.-L. (2014). Determinant Factors of the Capital Structure of a Firm- an Empirical Analysis. Procedia Economics and Finance, 15, 1447-1457. https://doi.org/10.1016/s2212-5671(14)00610-8

Steven, S., \& Lina, L. (2011). Faktor-faktor yang mempengaruhi kebijakan hutang perusahaan manufaktur. Jurnal Bisnis dan Akuntansi, 13(3), 163-181. https://doi.org/10.34208/jba.v13i3.232

Sutomo, S., Wahyudi, S., Rini Demi Pangestuti, I., \& Muharam, H. (2019). Determinants of financing decision: empirical evidence on manufacturing firms in Indonesia. Investment Management and Financial Innovations, 16(2), 159-170. https://doi.org/10.21511/imfi.16(2).2019.14

Vithessonthi, C., \& Tongurai, J. (2015). The effect of firm size on the leverage-performance relationship during the financial crisis of 2007-2009. Journal of Multinational Financial Management, 29, 1-29. https://doi.org/10.2139/ssrn.2285980

Wahyudi, S., Goklas, F., Rita, M. R., Hersugondo, H., \& Laksana, R. D. (2019). The Determinants of Corporate Hedging Policy: A Case Study from Indonesia. International Journal of Economics \& Business Administration, 7(1), 113-129. 